\title{
PENERAPAN TERAPI GERAK TARI UNTUK MENURUNKAN GANGGUAN MOTORIK ANAK TUNAGRAHITA
}

\author{
Yemima Octaviani Haryono ${ }^{1}$, Setyorini ${ }^{2}$, Yustinus Windrawanto ${ }^{3}$ \\ ${ }^{1,2,3}$ Program Studi Bimbingan dan Konseling, Fakultas Keguruan dan IImu Pendidikan, \\ Universitas Kristen Satya Wacana, \\ e-mail: yemimaoctaviani7@gmail.com, setyorini@uksw.edu,yustinus.windrawanto@uksw.edu
}

\begin{abstract}
Abstrak
Jenis penelitian ini adalah kuasi eksperimen. Penelitian ini bertujuan untuk mengetahuii signifikasi penerapan terapi gerak tari dalam menurunkan gangguan motorik anak tunagrahita dii Sekolah Luar Biasa Wantuwirawan Salatiga. Teknik analisis data yang digunakan dalam penelitian inii adalah two paired sample t-test dengan menggunakan program SPSS for windows release 20.0. Dani hasil analisis data diperoleh hasil bahwa penerapan terapi gerak tari secara signifikan dapat menurunkan gangguan motorik anak tunagrahita di Sekolah Luar Biasa Wantuwirawan Salatiga dengan $p=0,034<0,050$.
\end{abstract}

Kata kunci: terapi gerak tari; gangguan motorik; anak tunagrahita

\begin{abstract}
The type of this research is quasi-experimental. The aims of this research to determine the significance of the application of dance movement therapy to reduce motoric disorders in children with mental disability at extraordinary school Wantuwirawan Salatiga. The data analysis technique was used two paired sample t-test and using the SPSS for Windows Release 20.0 program. The results of the data analysis shows that the application of dance movement therapy can significantly reduce motoric disorders in children at the extraordinary school Wantuwirawan Salatiga with $p=0.0340<050$.
\end{abstract}

Keywords: dance movement therapy; motoric disorders; children with mental disability

\section{Pendahuluan}

Setiap individu memiliki tugas perkembangan yang harus dicapai selama masa hidupnya. Tugas perkembangan merupakan tugas-tugas yang muncul pada suatu periode tertentu dari kehidupan individu, dan apabila berhasil dicapai, akan menimbulkan rasa bahagia serta membawa ke arah keberhasilan dalam melaksanakan tugas-tugas perkembangan berikutnya. Sebaliknya, apabila timbul kegagalan, akan menimbulkan rasa tidak bahagia dan kesulitan dalam menghadapi tugas-tugas perkembangan berikutnya (Havighurst dalam Soetjiningsih, 2012). Ketidakmampuan individu dalam melaksanakan tugas perkembangannya, dapat dipengaruhi oleh beberapa faktor seperti; tingkat perkembangan yang mundur, tidak ada kesempatan untuk berkembang, tidak ada motivasi, kesehatan yang buruk, cacat tubuh dan memiliki kecerdasan yang rendah (Hurlock dalam Soetjiningsih, 2012).

Demikian juga dengan anak tunagrahita yang memiliki keterbatasan fisik, sehingga mempengaruhi tugas perkembangannya sebagai seorang individu. Anak tunagrahita dapat dikatakan sebagai anak dengan hambatan perkembangan (Delphie, 2006). Menurut Kirk dan Gallagher (dalam Purwanta, 2012) tunagrahita adalah suatu kondisi keterbelakangan mental dan memiliki intelegensi (IQ) rendah, dibawah rata-rata intelegensi (IQ) individu normal (85-115). Menurut Delphie (2005) anak tunagrahita memiliki gangguan penyerta yang melekat pada diri anak, salah satunya adalah gangguan motorik. Gangguan motorik ini dapat berupa kekakuan, kelumpuhan, gerakan yang tidak terkendali, gangguan gerakan ritmis dan gangguan keseimbangan gerak Asjjari (dalam Purwanta, 2012). Gangguan motorik yang menyertai anak tunagrahita diklasifikasikan dalam kelompok anak hiperaktivitas, hipoaktivitas dan kurang koordinasi (Asjjari dalam Purwanta, 2012). 
Gangguan motorik juga dialami beberapa anak tunagrahita di SLB Wantuwirawan Salatiga. Beberapa anak tunagrahita di SLB Wantuwirawan Salatiga ini, mengalami gangguan motorik seperti hiperaktivitas, hipoaktivitas dan kurang koordinasi. Menurut hasil pengamatan yang telah dilakukan peneliti, gangguan motorik (hiperaktivitas) yang dialami anak tunagrahita seperti melakukan aktivitas gerak yang berlebih, mengganggu teman, dan berbicara dengan konotasi negatif ketika proses pembelajaran di kelas. Gangguan motorik (hipoaktivitas) yang dialami anak tunagrahita seperti munculnya rasa malu yang berlebihan, rasa takut yang berlebihan dan sukar diajak berbicara ketika proses pembelajaran di kelas. Gangguan motorik (kurang koordinasi) yang dialami anak tunagrahita seperti sukar untuk bergerak, gerakan anggota tubuh tidak terarah dan sering keliru dalam menerima rangsangan (pertanyaan, arahan, sentuhan dan sebagainya). Ketiga jenis gangguan motorik yang dialami anak tunagrahita di SLB Wantuwirawan Salatiga ini dapat menjadi penghambat dalam kehidupan anak di lingkungan keluarga, sekolah, dan masyarakat yang menyebabkan munculnya perilaku non-adapif.

Keberadaan layanan bimbingan dan konseling (BK) di SLB memiliki peran penting dalam hal perubahan perilaku non-adaptif. Layanan BK ini bertujuan untuk memfasilitasi perkembangan diri sesuai dengan kemampuan (potensi), aktualisasi diri, dan membantu mengatasi kelemahan serta hambatan perkembangan anak tunagrahita (Johnsen dan Skjorten dalam Delphie, 2005). Layanan BK dapat diwujudkan melalui metode permainan terapi yang bersifat energik, eksplorasi, latihan secara teratur, dan pengembangan psikomotor (Delphie, 2005). Salah satunya melalui terapi gerak tari. Terapi ini menggunakan gerakan tari sebagai sarana komunikasi nonverbal, mengekspresikan emosi, relaksasi fisik, dan peningkatan kesadaran diri (Toombs dalam Gruenberg dan Miller, 2011). Layanan BK melalui terapi gerak tari ini diharapkan mampu untuk membimbing anak tunagrahita untuk dapat menyesuaikan diri dengan keadaan sekitar, sistem aturan yang ada, sehingga anak dapat menerima dan diterima di lingkungan tempat tinggalnya.

Kajian hasil penelitian menunjukkan bahwa ada keberhasilan layanan terapi gerak tari untuk menurunkan gangguan motorik. Namun terdapat perbedaaan tingkat keberhasilan pada penelitian-penelitian yang sudah ada. Hasil penelitian Rahmawati dkk (2018) yang berjudul "Menari Sebagai Media Dance Movement Therapy (DMT)" menunjukkan adanya peningkatan beberapa aspek dalam diri seseorang (kognitif, afektif, kesadaran diri, pengendalian emosi dan lain sebagainya) setelah diberikan terapi gerak tari. Hasil penelitian Dani dkk (2017) yang berjudul "Efek Penerapan Gerakan Tari dalam Menurunkan Hiperaktivitas pada Anak ADHD" menunjukkan adanya penurunan skor hiperaktivitas setelah diberikan layanan gerak tari. Hasil penelitian Shetty dan Shilpa (2015) yang berjudul "Effectiveness of Dance Movement Therapy on Attention Deficit Hyperactivity Disorder Children Aged Between 6-12 Years" menunjukkan adanya penurunan skor hiperaktivitas setelah diberikan layanan terapi gerak tari atau dengan kata lain layanan terapi gerak tari ini berpengaruh secara signifikan.

Subjek yang dipilih dalam penelitian ini adalah 3 anak tunagrahita yang memiliki gangguan motorik dengan tingkat gangguan cukup tinggi, yaitu AR (gangguan hiperaktivitas), BY (gangguan hipoaktivitas), AZ (gangguan kurang koordinasi gerak). Adanya gangguan motorik yang dialami anak tunagrahita ini yang menyebabkan perilaku non-adaptif muncul, sehingga menurut hasil wawancara dan pengamatan, ketiga anak tunagrahita ini seringkali mengganggu proses berjalannya belajar mengajar di sekolah.

Tujuan penelitian ini adalah untuk mengetahui signifikansi penerapan terapi gerak tari dalam menurunkan gangguan motorik anak tunagrahita di SLB Wantuwirawan Salatiga. Berdasarkan kajian riset relevan yang ada, penerapan terapi gerak tari memiliki hubungan yang erat dengan gangguan motorik (gangguan gerak), maka hipotesis penelitian ini adalah "penerapan terapi gerak tari secara signifikan dapat menurunkan gangguan motorik anak tunagrahita di SLB Wantuwirawan Salatiga.

\section{Metode}

Jurnal Mimbar IImu | 54 
Penelitian eksperimen kuasi ini bertujuan untuk membuktikan ada atau tidaknya signifikansi penerapan terapi gerak tari untuk menurunkan gangguan motorik yang dialami anak tunagrahita di SLB Wantuwirawan Salatiga. Eksperimen kuasi ini tidak menggunakan kelompok kontrol. Berikut rancanangan penelitian ekperimen kuasi :

Tabel 1. Rancangan Penelitian

\begin{tabular}{cccc}
\hline Group & Pretest & Perlakuan & Postest \\
\hline Eksperimen & $\mathrm{Y}_{1}$ & $\mathrm{X}$ & $\mathrm{Y}_{2}$ \\
\hline
\end{tabular}

$\mathrm{Y}_{1} \quad$ : Pretest gangguan motorik kelompok eksperimen

$\mathrm{X} \quad$ : Penerapan layanan BK melalui terapi gerak tari

$\mathrm{Y}_{2} \quad$ : Postest gangguan motorik kelompok eksperimen

Tes awal diberikan untuk mengetahui $Y_{1}$ (pre test) yaitu mengukur seberapa besar tingkat gangguan motorik (hiperaktivitas, hipoaktivitas dan kurang koordinasi) pada kelompok eksperimen. Kemudian pada kelompok eksperimen diberi perlakuan $X$ atau variabel bebas (terapi gerak tari) dalam jangka waktu tertentu. Terakhir, dilakukan tes akhir untuk mengukur $Y_{2}$ (post test) atau variabel terikat (gangguan motorik berupa hiperaktivitas, hipoaktivitas, dan kurang koordinasi), dan untuk mengetahui ada tidaknya penurunan gangguan motorik (hiperaktivitas, hipoaktivitas dan kurang koordinasi) pada kelompok eksperimen setelah diberi perlakuan.

Subjek penelitian sudah ditentukan yaitu berjumlah 3 orang anak tunagrahita yang masing-masing memiliki gangguan motorik yang berbeda, AR (gangguan hiperaktivitas), BY (gangguan hipoaktivitas), AZ (gangguan kurang koordinasi gerak). Ketiga subjek penelitian ini berusia 16-18 tahun, namun memiliki tingkat perkembangan yang tidak sesuai dengan anak seusianya, perkembangannya setara dengan anak di tingkat sekolah dasar.

Instrumen yang digunakan dalam penelitian ini adalah pedoman observasi gangguan motorik dari teori Asjjari (dalam Purwanta, 2012) dimana item-item gangguan motorik bersifat checklist yang akan diisi oleh guru pendamping dengan 4 kemungkinan jawaban, yaitu nomor 4 adalah pilihan jawaban jika anak tidak mampu melakukan aktivitas gerak walaupun dengan bantuan orang lain, pilihan jawaban nomor 3 jika anak mampu melakukan aktivitas gerak dengan banyak bantuan dari orang lain, pilihan jawaban nomor 2 jika anak mampu melakukan aktivitas gerak dengan sedikit bantuan dari orang lain, pilihan jawaban nomor 1 jika anak mampu melakukan aktivitas gerak tanpa bantuan orang lain. Kemudian instrumen kedua berupa desain terapi gerak tari berdasarkan teori Delphie (2016). Desain terapi gerak tari ini menjelaskan bahwa terdapat delapan kali pertemuan layanan dengan penyajian materi latihan gerak tari secara bertahap, berawal dari latihan gerakan dasar (locomotor), gerakan manipulative, gerakan nonmanipulative dan pada akhir rangkaian latihan, gerakan-gerakan tari diulang secara menyeluruh. Latihan gerak tari ini memanfaatkan satu tarian kreasi lengkap dengan iringan musik dan properti tari.

Uji validitas yang digunakan dalam menguji kebenaran dan ketepatan pedoman observasi gangguan motorik dari teori Ajjari (dalam Purwanta, 2012). Uji validitas ini menggunakan uji validitas konstruk. Menurut Sugiyono (2009) validitas konstruk merupakan uji validitas menggunakan pendapat dari ahli (judgment experts), dalam hal ini setelah instrumen dikonstruksi tentang aspek-aspek yang akan diukur dengan berlandaskan teori tertentu, maka selanjutnya akan dikonsultasikan dengan ahli. Kami sebagai peneliti meminta dua orang dosen untuk membantu uji validitas konstruk, yaitu Drs. Tritjahjo Danny Susilo, M.Si selaku dosen mata kuliah Pemahaman Individu Non Tes dan Sapto Irawan, S.Pd, M.Pd selaku dosen mata kuliah Manajemen Pendidikan dan Kecakapan Hidup. Berikut hasil uji validitas konstruk:

Tabel 2. Uji Validitas Konstruk 


\begin{tabular}{|c|c|c|}
\hline No. & Nama Dosen Ahli & Hasil Revisi Instrumen \\
\hline 1. & $\begin{array}{l}\text { Drs. Tritjahjo Danny Susilo, } \\
\text { M.Si }\end{array}$ & $\begin{array}{l}\text { Isi panduan observasi harus } \\
\text { disesuaikan dengan teori gangguan } \\
\text { motorik. } \\
\text { 2. Perlu adanya teori gangguan motorik } \\
\text { yang disesuaikan dengan usia } \\
\text { perkembangan anak. } \\
\text { 3. Perhatikan kembali sistem skoring } \\
\text { panduan observasinya. }\end{array}$ \\
\hline 2. & Sapto Irawan, S.Pd, M.Pd & $\begin{array}{l}\text { 1. Perlu adanya sub indikator. } \\
\text { 2. Perlu ada penyesuaian setiap item } \\
\text { dengan indikator. } \\
\text { 3. Setiap item yang terdapat pada } \\
\text { panduan observasi harus menunjukkan } \\
\text { gangguan motorik (gerak) bukan } \\
\text { gangguan psikis. }\end{array}$ \\
\hline
\end{tabular}

Teknik analisis data menggunakan teknik analisis data Two paired sample t-test dengan bantuan program SPSS windows release 20.0. Menurut Widiyanto (2013), Two paired sample t-test adalah metode pengujian data yang digunakan untuk mengkaji keefektifan perlakuan (treatment). Dasar pengambilannya jika Asymp. sig<0,05 maka hipotesis diterima dan sebaliknya jika nilai Asymp.sig>0,05 maka hipotesis ditolak.

\section{Hasil dan Pembahasan}

Proses pengumpulan data dalam penelitian eksperimen ini dilakukan dua tahapan, yaitu pre-test dan post-test. Ketiga subjek dalam penelitian ini mengalami gangguan motorik yang berbeda (hiperaktivitas, hipoaktivitas dan kurang koordinasi gerak) yang diberikan treatment atau perlakuan berupa layanan terapi gerak tari. Pelaksanaan eksperimen yang dilakukan peneliti dengan subjek ini berdasarkan tahap-tahap pelaksanaan sebagai berikut : 1. Pre-test (Tes awal)

Dalam penelitian ini, pre-test atau tes awal dilakukan pada tanggal 9 November 2018 dengan memberikan pedoman observasi tentang gangguan motorik yang diisi oleh guru kelas (pendamping) kemudian dilakukan pengamatan ketika peneliti mencontohkan gerakan-gerakan tari dan ditirukan oleh subjek penelitian. Berikut hasil observasi gangguan motorik yang dialami subjek penelitian:

Tabel 3. Hasil Pre-test Gangguan Motorik Anak Tunagrahita

\begin{tabular}{ccc}
\hline No. & Nama & Skor \\
\hline 1. & AR & 68 \\
2. & BY & 63 \\
3. & AZ & 57 \\
\hline
\end{tabular}

2. Treatment (Perlakuan)

Treatment atau perlakuan diberikan kepada subjek penelitian dengan tujuan dapat membantu menurunkan gangguan motorik yang dialami. Treatment atau perlakuan ini berupa terapi terapi gerak tari. Peneliti memanfatkan media tari kreasi yaitu tari "Yamko Rambe Yamko". Dalam tarian "Yamko Rambe Yamko" ini, peneliti membagi gerak-gerak tari yang ada, dengan mengklasifikasikannya ke dalam tiga konsep terapi gerak tari, yaitu gerakan locomotor (dasar), gerakan manipulative, dan gerakan nonmanipulative. Tujuan yang akan dicapai dari treatment atau perlakuan ini tidak untuk menghafal tarian, namun menjadikan gerak-gerak yang terdapat dalam tarian "Yamko Rambe Yamko" sebagai media 
terapi gangguan motorik (gangguan gerak) yang dialami subjek penelitian. Adapun pelaksanaan eksperimen yang dilakukan oleh peneliti dengan tahap-tahap sebagai berikut:

a. Pertemuan Pertama

Pertemuan pertama dilaksanakan pada tanggal 14 Januari 2019. Pada pertemuan ini peneliti memberikan materi untuk pertemuan pertama yaitu "Membangun Relasi dan Gerak Pemanasan Otot Tubuh". Hal ini dilakukan agar peneliti dan subjek penelitian dapat saling mengenal, memahami dan melatih kelenturan otot gerak tubuh. Pada pertemuan pertama ini, berdurasi 60 menit. Terdapat 10 materi gerak pemanasan otot tubuh, setiap materi diulang sebanyak dua kali dan setiap subjek penelitian mencoba sampai dapat melakukan gerakan yang dicontohkan. Pada akhir pertemuan, peneliti memberikan pujian dan motivasi kepada subjek penelitian tentang gerakan-gerakan yang telah dilakukan. Peneliti juga melakukan refleksi perasaan kepada masing-masing subjek penelitian, merencanakan pertemuan selanjutnya dan menutupnya dengan doa.

b. Pertemuan Kedua

Pertemuan kedua dilaksanakan pada tanggal 16 Januari 2019. Pada pertemuan ini peneliti memberikan materi bimbingan yaitu "Mempelajari Gerak Locomotor (gerak dasar)" dengan durasi waktu selama 60 menit. Pada pertemuan kedua ini, peneliti mengajak subjek untuk melakukan pemanasan otot tubuh agar tidak terjadi cidera, selanjutnya peneliti mencontohkan gerakan locomotor dengan iringan musik tari "Yamko Rambe Yamko". Dalam kegiatan bimbingan ini terdapat 10 materi gerak locomotor yang harus dilakukan subjek. Setelah selesai kegiatan terapi gerak tari ini, peneliti memberikan pujian dan motivasi kepada subjek penelitian tentang gerakan-gerakan yang telah dilakukan. Peneliti juga melakukan refleksi perasaan kepada masing-masing subjek penelitian, merencanakan pertemuan selanjutnya dan menutupnya dengan doa.

c. Pertemuan Ketiga

Pertemuan ketiga dilaksanakan pada tanggal 17 Januari 2019. Pada pertemuan ini peneliti memberikan materi bimbingan yaitu "Mempelajari Gerak Locomotor (gerak dasar)" dengan durasi waktu selama 60 menit. Perbedaan pertemuan kedua dan ketiga adalah pertemuan kedua untuk memberikan materi namun pertemuan ketiga subjek diminta untuk mempraktekkan kembali materi gerak locomotor pada pertemuan kedua. Peneliti mencontohkan gerakan locomotor dengan iringan musik tari "Yamko Rambe Yamko". Dalam kegiatan bimbingan ini terdapat 10 materi gerak locomotor yang harus dilakukan subjek. Setelah selesai kegiatan terapi gerak tari ini, peneliti memberikan pujian dan motivasi kepada subjek penelitian tentang gerakan-gerakan yang telah dilakukan. Peneliti juga melakukan refleksi perasaan kepada masing-masing subjek penelitian, merencanakan pertemuan selanjutnya dan menutupnya dengan doa.

d. Pertemuan Keempat

Pertemuan keempat dilaksanakan pada tanggal 21 Januari 2019. Pada pertemuan ini peneliti memberikan materi bimbingan yaitu "Mempelajari Gerak Manipulative" dengan durasi waktu selama 60 menit. Peneliti mencontohkan gerakan manipulative dengan iringan musik tari "Yamko Rambe Yamko". Dalam kegiatan bimbingan ini terdapat 4 materi gerak manipulative yang harus dilakukan subjek. Materi gerak manipulative ini menggunakan alat berupa gendang kecil dan materi geraknya pun divariasi dengan memukul gendang serta mengayunkan gendang. Setelah selesai kegiatan terapi gerak tari ini, peneliti memberikan pujian dan motivasi kepada subjek penelitian tentang gerakan-gerakan yang telah dilakukan. Peneliti juga melakukan refleksi perasaan kepada masing-masing subjek penelitian, merencanakan pertemuan selanjutnya dan menutupnya dengan doa.

e. Pertemuan Kelima

Pertemuan kelima dilaksanakan pada tanggal 23 Januari 2019. Pada pertemuan ini peneliti memberikan materi bimbingan yaitu "Mempelajari Gerak Manipulative" dengan durasi waktu selama 60 menit. Perbedaan pertemuan keempat dan kelima adalah pertemuan keempat untuk memberikan materi namun pertemuan kelima subjek diminta untuk mempraktekkan kembali materi gerak manipulative pada pertemuan keempat. Peneliti mencontohkan gerakan manipulative dengan iringan musik tari "Yamko Rambe Yamko". Dalam kegiatan bimbingan ini terdapat 4 materi gerak manipulative yang harus 
dilakukan subjek. Masing-masing subjek sudah dapat mengkoordinasikan antara gerakan tubuh dengan memukul gendang sesuai irama musik. Peneliti juga melakukan refleksi perasaan kepada masing-masing subjek penelitian, merencanakan pertemuan selanjutnya dan menutupnya dengan doa.

\section{f. Pertemuan Keenam}

Pertemuan keenam dilaksanakan pada tanggal 24 Januari 2019. Pada pertemuan ini peneliti memberikan materi bimbingan yaitu "Mempelajari Gerak Non-manipulative" dengan durasi waktu selama 60 menit. Peneliti mencontohkan gerakan non-manipulative dengan iringan musik tari "Yamko Rambe Yamko". Dalam kegiatan bimbingan ini terdapat 5 materi gerak non-manipulative yang harus dilakukan subjek. Materi gerak non-manipulative ini menggerakkan badan namun tidak berpindah posisi atau tempat dan tidak menggunakan alat menari. Setelah selesai kegiatan terapi gerak tari ini, peneliti memberikan pujian dan motivasi kepada subjek penelitian tentang gerakan-gerakan yang telah dilakukan. Peneliti juga melakukan refleksi perasaan kepada masing-masing subjek penelitian, merencanakan pertemuan selanjutnya dan menutupnya dengan doa.

g. Pertemuan Ketujuh

Pertemuan ketujuh dilaksanakan pada tanggal 28 Januari 2019. Pada pertemuan ini peneliti memberikan materi bimbingan yaitu "Mempelajari Gerak Non-manipulative" dengan durasi waktu selama 60 menit. Perbedaan pertemuan keenam dan ketujuh adalah pertemuan keenam untuk memberikan materi namun pertemuan ketujuh subjek diminta untuk mempraktekkan kembali materi gerak non-manipulative. Peneliti mencontohkan gerakan non-manipulative dengan iringan musik tari "Yamko Rambe Yamko". Dalam kegiatan bimbingan ini terdapat 5 materi gerak non-manipulative yang harus dilakukan subjek. Pada pertemuan ketujuh ini, dengan materi yang sama dengan pertemuan keenam, masing-masing subjek sudah menunjukkan peningkatan kemampuan motoriknya, khususnya untuk gerak-gerak bergoyang, mengayunkan tangan dan kaki. Setelah selesai kegiatan terapi gerak tari ini, peneliti memberikan pujian dan motivasi kepada subjek penelitian tentang gerakan-gerakan yang telah dilakukan. Peneliti juga melakukan refleksi perasaan kepada masing-masing subjek penelitian, merencanakan pertemuan selanjutnya dan menutupnya dengan doa.

h. Pertemuan Kedelapan

Pertemuan kedelapan dilaksanakan pada tanggal 30 Januari 2019. Pada pertemuan ini peneliti memberikan materi bimbingan yaitu "Gerak Locomotor,Manipulative dan Nonmanipulative" dengan durasi waktu selama 60 menit. Peneliti mengulang ketiga konsep terapi gerak tari, yaitu gerak locomotor, dilanjutkan dengan gerak manipulative, dan terakhir gerak non-manipulative. Kegiatan terapi tari ini berdurasi 60 menit. Peneliti melakukan pengamatan pada masing-masing subjek dalam kegiatan terapi gerak tari ini. Pada pertemuan kedelapan ini, subjek sudah terlihat mengalami peningkatan kemampuan motorik dan ini merupakan pertemuan yang terakhir. Kemudian guru kelas sebagai observer diminta untuk melakukan pengamatan kembali dan mengisi pedoman observasi yang telah disediakan. Setelah selesai kegiatan terapi gerak tari ini, peneliti memberikan pujian dan motivasi kepada subjek penelitian tentang gerakan-gerakan yang telah dilakukan. Peneliti juga melakukan refleksi perasaan kepada masing-masing subjek penelitian, kesan dan pesan selama mengikuti kegiatan terapi gerak tari dan menutupnya dengan doa.

\section{Post Test (Tes Akhir)}

Pengumpulan data post test dilakukan setelah serangkaian kegiatan bimbingan menggunakan teknik terapi gerak tari berakhir. Post test dilaksanakan pada tanggal 30 Januari 2019. Pedoman observasi pada post test tentang kemampuan motorik subjek penelitian sama dengan pedoman observasi pada pre test. Adapun hasil post test adalah sebagai berikut:

Tabel 4. Hasil Post-test Gangguan Motorik Anak Tunagrahita 


\begin{tabular}{ccc}
\hline No. & Nama & Skor \\
\hline 1. & AR & 56 \\
2. & BY & 47 \\
3. & AZ & 34 \\
\hline
\end{tabular}

Tabel 5. Perbedaan Skor Pre Test dan Post Test

\begin{tabular}{lccc}
\hline No. & Nama & $\begin{array}{c}\text { Skor Pre } \\
\text { Test }\end{array}$ & $\begin{array}{c}\text { Skor Post } \\
\text { Test }\end{array}$ \\
\hline 1. & AR & 68 & 56 \\
2. & BY & 63 & 47 \\
3. Jumlah & AZ & 57 & 34 \\
Rata-rata & & 188 & 137 \\
\hline
\end{tabular}

Dari data pada tabel 5 dapat dilihat bahwa skor rata-rata pre test sebesar 63 dan post test sebesar 46. Selanjutnya dilakukan perhitungan analisis data dengan menggunakan teknik analisis data Two paired sample t-test untuk mengetahui perbandingan keadaan gangguan motorik subjek sebelum diberikan treatment (pre test) dan sesudah diberikan treatment (post test). Hasil penghitungan Two paired sample t-test diketahui bahwa nilai Asymp.sig (2 tailed) sebesar 0,034 ( $\mathrm{p}<0,05)$, yang berarti bahwa ada perbedaan yang signifikan antara hasil pre test dan post test pada gangguan motorik yang dialami subjek penelitian (anak tunagrahita) sesudah pelaksanaan layanan bimbingan dan konseling melalui terapi gerak tari di SLB Wantuwirawan Salatiga. Hipotesis yang telah dirumuskan juga diterima yaitu, penerapan terapi gerak tari secara signifikan dapat menurunkan gangguan motorik anak tunagrahita di SLB Wantuwirawan Salatiga. Berikut gambar proses layanan terapi gerak tari:
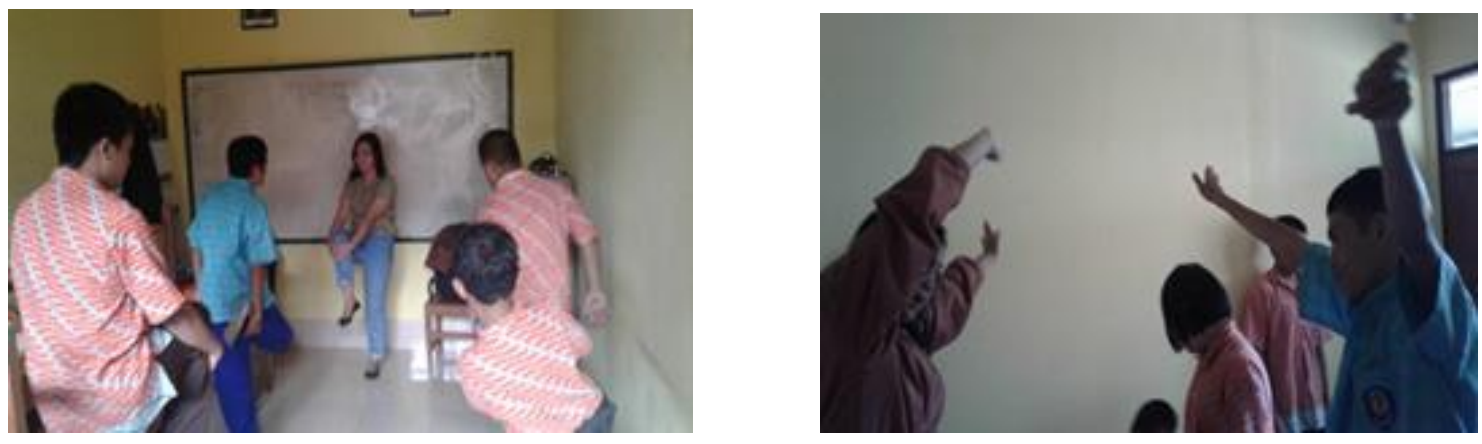

Gambar 1. proses terapi gerak tari

Layanan bimbingan dan konseling melalui terapi gerak tari secara signifikan dapat menurunkan gangguan motorik anak tunagrahita di SLB Wantuwirawan Salatiga. Subjek pertama dengan gangguan motorik berupa hiperaktivitas, sebelum diberikan terapi gerak tari memiliki skor gangguan motorik sebesar 68 , kemudian setelah diberikan terapi gerak tari dengan 8 kali pertemuan, diketahui ada penurunan skor gangguan motorik menjadi 56 . Perubahan ini dapat dilihat dari emosi subjek pertama yang sulit untuk dikendalikan sehingga menyebabkan gerakan tubuh yang nampak menjadi tidak sesuai dengan perilaku siswa pada umumnya. Setelah diberikan terapi gerak tari, subjek pertama menjadi lebih tenang dan fokus terhadap aktivitas gerak yang dilakukan.

Subjek kedua dengan gangguan motorik berupa hipoaktivitas, sebelum diberikan terapi gerak tari memiliki skor gangguan motorik sebesar 63 , kemudian setelah diberikan terapi gerak tari dengan 8 kali pertemuan, diketahui ada penurunan skor gangguan motorik menjadi 47. Keadaan subjek kedua sebelum diberikan terapi gerak tari, yaitu nampak 
gelisah, rasa takut yang berlebihan terhadap orang di sekitarnya, dan malu untuk mengikuti aktivitas gerak yang diajarkan. Namun, ketika melalui 8 kali pertemuan terapi gerak tari, subjek kedua ini mengalami perubahan perilaku yang lebih baik dari sebelumnya. Subjek kedua ini sudah mampu menyesuaikan diri dengan aktivitas gerak yang diajarkan, bahkan kekakuan gerak yang dialaminya nampak berkurang.

Subjek ketiga dengan gangguan motorik berupa kurang koordnasi, sebelum diberikan terapi gerak tari memiliki skor gangguan motorik sebesar 57, kemudian setelah diberikan terapi gerak tari dengan 8 kali pertemuan, diketahui ada penurunan skor gangguan motorik menjadi 34. Keadaan gangguan motorik yang dialami subjek ketiga ini, dirasa tidak dalam kategori parah seperti subjek pertama dan kedua. Subjek ketiga ini diawal pengukuran skor pre test, memiliki skor gangguan motorik yang lebih rendah dibandingkan kedua subjek lainnya. Dalam kegiatan terapi gerak tari ini, subjek ketiga nampak mampu untuk mengikuti aktivitas gerak yang diajarkan, namun kekurangannya adalah belum mampu untuk menyeimbangkan gerak tubuh, hal ini yang memungkinkan subjek ketiga membutuhkan pegangan untuk berdiri dengan satu kaki, atau untuk melompat. Kemudian untuk pengendalian emosi subjek ketiga juga belum mampu menguasainya, nampak sedih, bahkan marah hingga menyakiti subjek penelitian lainnya. Dengan adanya terapi gerak tari ini subjek ketiga mengalami penurunan gangguan motorik, subjek mampu menyeimbangkan gerak tubuh dan mampu mengontrol emosi yang berlebihan.

Dalam kegiatan terapi gerak tari ini, peneliti menggunakan sarana tari kreasi Yamko Rambe Yamko dari Papua. Peneliti menggunakan tarian ini karena tarian Yamko Rambe Yamko ini terdiri dari beberapa gerakan yang lambat dan energik. Hal ini dirasa sesuai dengan kebutuhan subjek penelitian yang memerlukan eksplorasi gerak tubuh agar tidak kaku dan melatih konsentrasi. Peneliti juga mengklasifikasikan bentuk-bentuk gerak tari yang ada ke dalam tiga konsep terapi gerak tari menurut Delpie (2006) yaitu gerak locomotor, gerak manipulative dan gerak non-manipulative. Terapi gerak tari ini juga menggunakan media tari berupa alat musik kendang kecil untuk mempelajari materi gerak manipulative. Tujuan dari digunakannya alat musik kendang kecil ini adalah agar subjek terangsang untuk menggunakan alat-alat yang ada disekitarnya sesuai dengan kegunaannya.

Hasil penelitian terbukti efektif untuk menurunkan gangguan motorik yang dialami anak tunagrahita. Subjek AR, BY dan AZ mampu mengubah perilaku non-adaptif yang mereka miliki, menjadi perilaku yang adaptif. Ketiga subjek penelitian ini mampu berperilaku sesuai dengan aturan-aturan di lingkungan sekolah, misalnya bersikap tenang, fokus atau konsentrasi dalam hitungan 10-15 menit, mengatur emosi yang berlebihan (sedih, marah, gembira dan lain sebagainya). Hal ini mendukung teori menurut Delphie (2006) terapi gerak tari mampu memberikan rasa kegembiraan, pencapaian atas pengendalian gerak tubuh dan dapat meningkatkan kemampuan emosional, sosial serta kognitif anak tunagrahita. Namun, peneliti mengamati jika layanan terapi gerak tari ini tidak dilakukan secara rutin, maka subjek akan kembali ke kondisi awal dengan gangguan motorik yang dialaminya (hiperaktivitas, hipoaktivitas, dan kurang koordinasi).

Hasil penelitian ini juga mendukung beberapa penelitian yang sudah ada, seperti hasil penelitian Rahmawati dkk (2018), Dani dkk (2017), serta Shetty dan Shilpa (2015) bahwa terapi gerak tari ini dapat menurunkan gangguan motorik. Namun yang membedakan hasil penelitian ini dengan penelitian relevan lainnya adalah subjek yang diteliti. Peneliti menemukan permasalah gangguan motorik ini terhadap anak-anak tunagrahita yang berusia remaja (16-18 tahun) namun memiliki tingkat perkembangan yang lambat. Kemudian gangguan motorik yang diteliti tidak hanya satu atau dua gangguan, melainkan tiga gangguan sekaligus yang terklasifikasi dalam gangguan motorik (hiperaktivitas, hipoaktivitas dan kurang koordinasi, dan keadaan seperti ini yang memungkinkan banyak terjadi hambatan dalam pelaksanaan terapi gerak tari, namun dapat teratasi. Terakhir, dapat dilihat pada bidang keilmuannya, penelitian relevan yang ada memiliki latar belakang bidang keilmuan psikologi, keperawatan anak (kesehatan) dan pendidikan luar biasa serta seni tari. Namun peneliti mencoba menerapkannya kedalam bidang keilmuan bimbingan dan konseling. Peneliti mencoba untuk menjadikan terapi gerak tari ini sebagai layanan 
bimbingan untuk membantu anak-anak tunagrahita dapat berperilaku adaptif sesuai dengan lingkungan di keluarga, sekolah dan di masyarakat.

\section{Simpulan dan Saran}

Berdasarkan hasil analisis data penelitian dapat disimpulkan bahwa terapi gerak tari dapat menurunkan gangguan motorik anak tunagrahita di SLB Wantuwirawan Salatiga yang terbukti dengan hasil Asymp.sig (2 tailed) sebesar 0,034 ( $p<0,05)$. Saran untuk anak tunagrahita yang telah diberikan terapi gerak tari diharapkan untuk tetap bersemangat dan aktif dalam proses penyembuhan gangguan motorik. Jika proses ini dilakukan secara rutin dan mendapat respon positif dari anak tunagrahita, maka anak tunagrahita akan mengalami perubahan perilaku menjadi adaptif, anak dapat menerima lingkungan sekitar dan dapat diterima juga. Saran untuk guru, diharapkan dapat mencoba menerapkan layanan bimbingan konseling melalui terapi gerak tari ini kepada anak tunagrahita, sehingga dapat mendukung aktivitas belajar mengajar di kelas menjadi lebih efektif dan membantu anak keluar dari permasalahan motorik yang dialami. Pihak sekolah juga dapat menjadikan penelitian ini sebagai acuan untuk mendukung dan memfasilitasi program layanan bimbingan konseling melalui terapi gerak tari. Program ini kedepannya tidak hanya untuk menurunkan atau menyembuhkan gangguan motorik anak tunagrahita, namun juga gangguan lain yang mungkin dialami anak tunagrahita. Peneliti lanjut dapat melakukan penelitian yang serupa pada subjek dan variabel yang berbeda. Karena dengan meneliti subjek dan variabel yang berbeda, dapat dibuktikan bahwa layanan terapi gerak tari ini dapat diberikan kepada subjek selain anak tunagrahita dengan permasalahan yang berbeda.

\section{Daftar Pustaka}

Buitelaar dan Paternotte. 2010. ADHD Attention Deficit Hyperactivity Disorder (Gangguan Pemusatan Perhatian dan Hiperaktivitas) Gejala, Diagnosis, Terapi, Serta Penanganannya di Rumah dan di Sekolah. Jakarta : Prenadamedia Group.

Delphie, Bandi. 2005. Bimbingan Konseling Untuk Perilaku Non-Adaptif. Bandung : Pustaka Bani Quraisy.

Delphie, Bandi. 2006. Pembelajaran Anak Tunagrahita. Bandung : PT. Refika Aditama.

Darmawan, Deni. 2014. Metode Penelitian Kuantitatif. Bandung : PT. Remaja Rosdakarya.

Gandasetiawan, Ratih Zimmer. 2009. Mengoptimalkan IQ dan EQ Anak Melalui Metode Sensorimotorik. Jakarta : Penerbit Libri.

Gruenberg, Ann M dan Miller, Regina. 2011. A Practical Guide to Early Childhod Inclusion (Effective Reflection). Boston. Pearson Eduction, Inc.

Jardin Mariposa.2006. Dance Therapy di http://www.jardinmariposa.com/index.php/en/instituto-de-danzaterapia-6/danzaterapia (diakses pada 9 juli 2018).

Komalasari, Gantina dkk. 2011. Asesmen Teknik Non Tes dalam Perspektif BK Komprehensif. Jakarta : PT. Indeks.

Leo, Sutanto. 2013. Kiat Jitu Menulis Skripsi, Tesis, dan Disertasi. Jakarta. PT. Gelora Aksara Pratama.

Magill, Ricard A. 2001. Motor Learning Concepts and Applications. Singapore : McGrawHill Compenies, Inc.

Purwanta, Edi. 2012. Modifikasi Perilaku. Yogyakarta : Pustaka Pelajar. 
Soetjiningsih, Christiana Hari. 2012. Perkembangan Anak (Sejak Pembuahan Sampai Dengan Kanak-kanak Akhir. Jakarta : Prenadamedia Group.

Sugiyono. 2009. Statistika Untuk Penelitian. Bandung : CV. Alfabeta.

Sugiyono. 2012. Metode Penelitian Kuantitatif Kualitatif dan R \& D. Bandung : CV. Alfabeta.

Widiayanto. 2013. Statistika Terapan. Jakarta : PT. Alex Media Komputindo.

Shilpa J, Asha P Shetty. 2015. Effectiveness of Dance Movement Therapy on Attention Deficit Hyperactivity Disorder Children Aged Between 6-12 Years. Manipal Journal of Nursing and Health Sciences.1(1) : 19-23.

Dani, Robik Anwar dkk. 2017. Efek Penerapan Terapi Gerakan Tari Dalam Menurunkan Hiperaktivitas Pada Anak ADHD. Prosiding Temu Ilmiah X Ikatan Psikologi Perkembangan Indonesia. (267-279). Semarang: Hotel Gracia.

Heter, Alyssa. 2017. Dance and Movement Therapy. GSW Journal of First-Year. 5(1) : 1-6.

Rahmawati, dkk. 2018. Menari Sebagai Media Dance Movement Therapy (DMT). Jurnal Pendidikan dan Kajian Seni. 3(1) : 31-46.

Ratnayanti, Rahajeng dan Kustiawan, Usep. 2014. Pengaruh Penerapan Pembelajaran Tari Kreasi Terhadap Kemampuan Motorik Kasar Siswa Tunagrahita di Sekolah Dasar Luar Biasa. Jurnal Ortopedagogia. 1(3) : 238-244.

Syofia, Ninon dan Suharti. 2016. Pelatihan Seni Tari dan Musik Sebagai Media Terapi Pada Anak Berkebutuhan Khusus di Sekolah Dasar Luar Biasa Silaing Bawah Kota Padang Panjang. 1(1) : 118-130.

Yuliastati. 2011. Pengaruh Latihan Rentang Gerak Sendi Terhadap Kekuatan Otot Dan Luas Gerak Sendi Anak Dengan Tuna Grahita Sedang Di Sekolah Luar Biasa Kota Bogor. Tesis tidak diterbitkan. Jakarta : Pascasarjana Universitas Indonesia Jakarta. 